Retraction

\title{
Retracted: A Simple, Sensitive Spectrophotometric Determination of Mosapride in Pharmaceutical Preparations Using Novel Reagent
}

\author{
Journal of Chemistry \\ Received 19 September 2020; Accepted 19 September 2020; Published 2 December 2020 \\ Copyright (C) 2020 Journal of Chemistry. This is an open access article distributed under the Creative Commons Attribution \\ License, which permits unrestricted use, distribution, and reproduction in any medium, provided the original work is \\ properly cited.
}

Journal of Chemistry has retracted the article titled "A Simple, Sensitive Spectrophotometric Determination of Mosapride in Pharmaceutical Preparations Using Novel Reagent" [1], as it was submitted for publication without the knowledge and approval of the co-authors G. Krishnamurthy Naidu, K. Suvardhan, M.V. Jyothi, and B.S. Sastry.

\section{References}

[1] G. K. Naidu, K. Suvardhan, M. V. Jyothi, B. S. Sastry, and P. Chiranjeevi, "A Simple, Sensitive Spectrophotometric Determination of Mosapride in Pharmaceutical Preparations Using Novel Reagent," E-Journal of Chemistry, vol. 1, no. 5, pp. 267-271, 2004. 


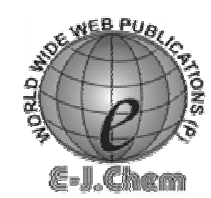

http://www.e-journal.net

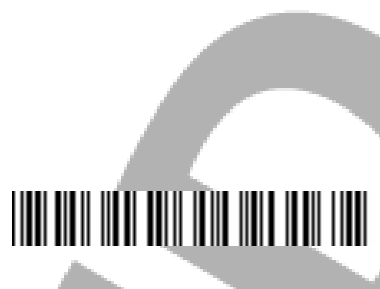

ISSN: 0973-4945; CODEN ECJHAO

E-Journal of Chemistry

Vol. 1, No. 5, pp 267-271, October 2004

\title{
A Simple, Sensitive Spectrophotometric Determination of Mosapride in Pharmaceutical Preparations Using Novel Reagent
}

\author{
G. KRISHNAMURTHY NAIDU ${ }^{1}$, K. SUVARDHAN ${ }^{3}$, M.V. JYOTHI, \\ B.S. SASTRY ${ }^{2 *}$ and P. CHIRANJEEVI ${ }^{3}$ \\ ${ }^{1}$ Department of Pharmacy, S.V. Govt. Polytechnic, Tirupati-517501, A.P., India. \\ ${ }^{2 *}$ Department of Pharmaceutical Sciences, Andhra University, Visakapatnam, A.P., India. \\ ${ }^{3}$ Environmental Monitoring Laboratories, Department of Chemistry, S.V University, \\ Tirupati-517502, A.P., India. E-mail: chiranjeevi_sai@yahoo.co.in
}

Received 17 September 2004; Accepted 10 October 2004

\begin{abstract}
A rapid, selective and sensitive spectrophotometric method for the determination of mosarpide in either pure form or in its formulations in pharmaceutical preparations is described. The method is based on the diazotization coupling reaction of mosapride with 1-naphthol in acidic medium to give red azo dye product with the $\lambda_{\max }$ of $500 \mathrm{~nm}$ and is stable for more than 12 hours at optimum condition, Beer's law is obeyed at concentration of 0.2 to $12 \mu \mathrm{g} \mathrm{mL} \mathrm{m}^{-1}$ at the wavelength of maximum absorbance. Common excipients used as additives in pharmaceutical preparations do not interfere in the proposed method. The developed method is highly reproducible and applied to wide variety of pharmaceutical formulation and the results were compared favourably with the reported method.
\end{abstract}

Keywords: Mosapride citrate, 1-Naphthol, Diazotization, Spectrophotometer, Pharmaceutical preparations.

\section{Introduction}

Mosapride citrate ${ }^{1}(\mathrm{I}), \quad(+/-)$ - 4-amino-5-chloro-2-ethoxy-N[[4-(4-flourobenzyl)-2morpholinyl] methyl ]Benzamide citrate dihydrate ${ }^{2}$ is used in gastrointestinal symptoms associated with chronic gastrointestinal symptoms associated with chronic gastritis. This drug is a selective 5-HT4 receptor agonist ${ }^{3-5}$. Spectrophotometric parameters were established for standardisation of the methods including statistical analysis of data ${ }^{6}$. There is no sensitive and simple analytical method in literature for the quantitative determination of mosapride in bulk drug and formulations. Few authors have developed spectrophotometric determination of mosapride in pharmaceutical preparations. But these methods offer certain disadvantage like, sensitivity and stability, for its determination. Therefore the authors have made some attempts to develop a highly sensitive method for determination of mosapride, 
based on diazotization coupling reaction to form red azo dye with $\lambda_{\max }$ of $500 \mathrm{~nm}$. The method has been successfully employed for determination of mosapride in pharmaceutical preparations and compared with reported method in literature ${ }^{7}$ in terms of sensitivity and stability.

\section{Experimental}

\section{Materials and Methods}

Analytical grade reagents were used. Double distilled water was used throughout the experiments. 1-naphthol was purchased from S.D fine Chemicals (INDIA) and used without further purification. Hydrochloric acid (AR), Sodium nitrite were used. Commercial dosage was purchased from local sources.

A HITACHI 2000 UV-Visible spectrophotometer with $1.0 \mathrm{~cm}$ matched quartz cell was employed to obtain electronic spectral measurements.

\section{Solutions}

Standard solution of mosapride $\left(1000 \mu \mathrm{g} \mathrm{mL}^{-1}\right)$ was prepared by dissolving $100 \mathrm{mg}$ of mosapride in $10 \mathrm{~mL}$ of absolute alcohol and then diluted to the mark in $100 \mathrm{~mL}$ standard flask. A working standard solution of each $25 \mu \mathrm{g} \mathrm{mL}^{-1}$ was prepared by further dilution. $0.2 \%$ solution of freshly prepared 1-naphthol in $5.0 \mathrm{~mL}$ of $1 \mathrm{~N}$ Sodium hydroxide. $5 \mathrm{~N}$ Hydrochloric acid and 3\% Sodium nitrite solution were used for the experiments.

\section{Procedure}

Aliquots of working standard solution of mosapride $(0.2$ to $14 \mu \mathrm{g})$ were transferred into a series of $100 \mathrm{~mL}$ calibrated flask. To each flask, $15 \mathrm{~mL}$ of Hydrochloric acid $(5 \mathrm{~N})$ and 2 $\mathrm{mL}$ of $3 \%$ Sodium nitrite solution were added and kept to stand for $10 \mathrm{~min}$ at room temperature. Then $2 \mathrm{~mL}$ of aqueous solution of ammonium sulphamate $(0.5 \% \mathrm{~W} / \mathrm{V})$ was added and the solution was shaken thoroughly. After $2 \mathrm{~min}, 1 \mathrm{~mL}$ of coupling agent, 1naphthol was added and diluted to mark with distilled water. The absorbance was measured at $500 \mathrm{~nm}$ against the corresponding reagent blank and calibration graph was constructed.

\section{Procedure for the assay of dosage of mosapride in commercial Samples}

Five tablets were powdered and a known weight of the powdered sample was dissolved in 5.0 $\mathrm{mL}$ absolute alcohol and filtered. The working standards were prepared by suitable dilution and the standard procedure was followed for the determination of mosapride in Tablets.

\section{Result and Discussion}

\section{Spectral Characteristics}

The proposed method involves diazotization coupling reaction of 1-naphthol with mosapride in acidic medium to produce the red coloured azo dye product with $\lambda_{\max }$ of $500 \mathrm{~nm}$ as shown in Figure 2.

\section{Optimisation of Reagent Concentration}

Various concentration and volume ranges for all the reagents were studied in detail. It was found that 1-naphthol in the range of 1-2 $\mathrm{mL}, 3 \mathrm{~mL}$ of mosapride, 1-2 $\mathrm{mL}$ of ammonium sulphamate, $5 \mathrm{~N}$ Hydrochloric acid in the range of $10-15 \mathrm{~mL}$ and $3 \%$ Sodium nitrite solution in the range of $1-2 \mathrm{~mL}$ were necessary to obtain a stable coloured product with maximum colour intensity. Required volumes of the reagents were hence used as noted in the standard procedure. 


\section{Stability}

The coloured product of mosapride formed by the proposed method was found to be stable for more than $12 \mathrm{~h}$ at room temperature. Reproducible results were obtained in the temperature range of $31-43^{\circ} \mathrm{C}$. An increase in temperature of above $43^{\circ} \mathrm{C}$ and below $30^{\circ} \mathrm{C}$, decreases the absorbance data, indicating the decomposition of the product. However a temperature of $31-43^{\circ} \mathrm{C}$ is recommended for the absorbance measurements of the coloured product.

\section{Optical characteristics}

Beer's law is obeyed over the mosapride concentration range over 0.2 to $12 \mu \mathrm{g} \mathrm{mL}^{-1}$ for 1 naphthol as coupling agent. Limit of Quantification (LOQ) were determined by taking the standard deviation $(\sigma)$ of the blank with respect to water and slope of calibration curve's multiplied by a factor 10. That means, LOQ is approximately 3.3 times Limit of Detection (LOD). Normally the LOQ slightly crosses the lower limit of Beer's law. But LOD is well below the lower limit of the Beer's law range. The upper limit of Beer Lambert law is determined by plot of absorbance against concentration at the value of $\lambda_{\max } 500 \mathrm{~nm}$. Beyond this limit, the correlation results were really affected. Hence the measurements were excluded above these limits to keep the linear relationship. The optical characteristic and precision data are presented in Table1.

Table 1 Optical characteristics and precision data of mosapride

\begin{tabular}{cc}
\hline Optical Characteristics and Precision data & Value \\
\hline Beer's law range $\left(\mu \mathrm{g} \mathrm{mL}^{-1}\right)$ & $0.2-12$ \\
$\lambda_{\max }(\mathrm{nm})$ & $500 \mathrm{~nm}$ \\
Stability & more than $12 \mathrm{~h}$ \\
Colour of the product & Red azo dye \\
Limit of detection $\left(\mu \mathrm{gL}^{-1}\right)$ & 0.621 \\
Limit of quantification $\left(\mu \mathrm{g} \mathrm{mL}^{-1}\right)$ & 0.2638 \\
Sandell's Sensitivity $\left(\mu \mathrm{cm}^{-2}\right)$ & 0.032 \\
Molar absorptivity $\left(1 \mathrm{~mol}^{-1} \mathrm{~cm}^{-1}\right)$ & $3.61 \times 10^{4}$ \\
Regression equation $\left(\mathrm{Y}^{\mathrm{a}}\right)$ & $5.71 \times 10^{-2}$ \\
Slope $(\mathrm{a})$ & $0.75 \times 10^{-2}$ \\
Intercept $(\mathrm{b})$ & 0.9980 \\
Correlation coefficient $(\mathrm{r})$ & 0.8936 \\
$\%$ Relative standard deviation & \pm 0.0017 \\
$\%$ Error & 0.18 to 15 \\
\hline Optimum range by photometric determination & $\left(\mu \mathrm{g} \mathrm{mL}^{-1}\right)$ \\
\hline
\end{tabular}

${ }^{\mathrm{a}} \mathrm{Y}=\mathrm{bx}+\mathrm{a}$; where $\mathrm{x}$ is the concentration in $\mu \mathrm{gmL}^{-1}{ }_{\mathrm{b}} \mathrm{n}=10^{\mathrm{c}}$ Ten replicates

\section{Reaction Sequence}

The 1-naphthol reacts with mosapride in acidic medium $\left(\mathrm{HCL}+\mathrm{NaNo}_{2}\right)$ to produce red coloured azo dye product with $\lambda_{\max }$ of $500 \mathrm{~nm}$. The reaction mechanism for the formation of product is shown in Figure 1. 


\section{Interference}

Under the diaoztization coupling reaction condition, problem of interference does not arise in the analysis of commercially available mosapride. The effects of additives associated with mosapride in its formulations were investigated using the developed method. The method does not suffer from common excipients and other substances

\section{Application}

Reproducibility of the method was checked out by 10 replicate determination at $6 \mu \mathrm{g} \mathrm{mL}^{-1}$. The application of the method for assay of pharmaceutical preparations was examined. The results of assay of the available tablets of mosapride are presented in Table 2. The actual weight of individual tablet is $5 \mathrm{mg}$. The analysis of the tablet was conducted from original state. The results are highly reproducible and assay of tablets were cross checked by reported method $^{7}$ which agree favourably.

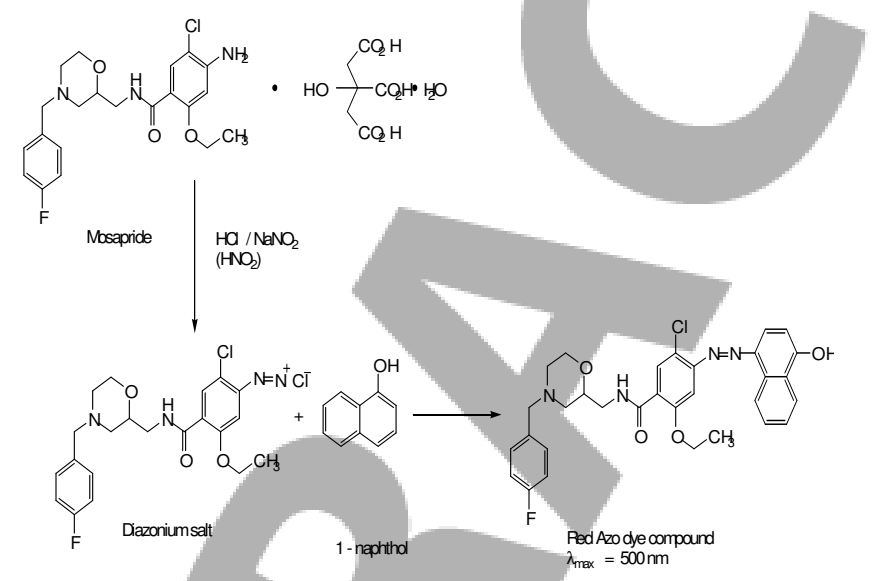

Figure 1. Reaction mechanism of mosapride with 1- naphthol

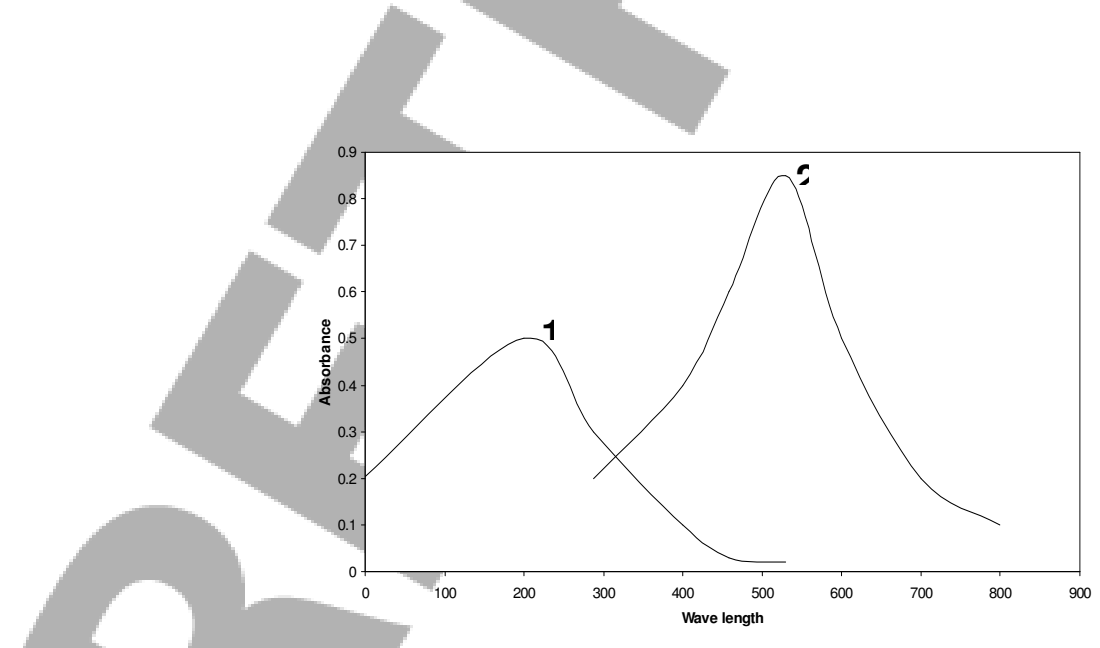

Figure 2. Absorption spectra of 1 Mosapride + reagent blank 
Table 2. Determination of mosapride in pharmaceutical preparation

\begin{tabular}{lccc}
\hline Samples & $\begin{array}{c}\text { Label claim } \\
(\mathrm{mg})\end{array}$ & \multicolumn{2}{c}{ Amount of drug found ${ }^{\mathrm{b}}$ in mg } \\
\cline { 3 - 4 } & 5 & $\begin{array}{c}\text { Proposed } \\
\text { Method }\end{array}$ & \begin{tabular}{c} 
Reported $^{\text {Method }^{7}}$ \\
\hline Tablet I $^{\mathrm{a}}$
\end{tabular} \\
Tablet II $^{\mathrm{a}}$ & 5 & 4.98 & 4.95 \\
\hline
\end{tabular}

${ }^{\mathrm{b}}$ Average of ten determination.

\section{Conclusion}

The proposed method is simple, selective and highly sensitive than the spectrophotometric method available in literature ${ }^{7}$. The statistical parameter and recovery study data clearly indicates the reproducibility and accuracy of the method. Thus, the method can be adopted as an alternative to the existing spectrophotometric methods. Analysis of the authentic samples containing mosapride showed no interference from the common additives and excipients. Hence recommended procedure is well suited for the assay and evaluation of drugs in pharmaceutical preparations in assure of high standard of quality control.

\section{References}

1. Yoshida. N, Kato S and Lto T Drugs of the future 1993, 18(6), 513.

2. Yosida K, Itogowa A and Lagawa M, Drugs 1993, 43(11), 1095.

3. Carisson L, Amos $\mathrm{J}$ G and Anderson B, The journal of Pharmacology and Experimental Therapeutics 1997, 282, 220.

4. Nehra D, Glowel P and Williams C P, GUT 1999, 44, 598.

5. Kanaizumi T, Journal of Smooth Muscle Research, 1990, 26, 161.

6. Murthyunjaya Swamy B H M, Malipatil S M and Appala Raju S, J. Indian Council of Chemists, 2001, 19(2), 60.

7. Prabhakar B K, Shobha Manjunath and Appala Raju S, J. Indian Council of Chemists, 2003,20 (1), 42. 